\title{
New species and records of Afrotropical Campoletis Förster, 1869 (Hymenoptera: Ichneumonidae: Campopleginae)
}

\author{
ZOLTÁN VAS \\ Hungarian Natural History Museum, Department of Zoology, Hymenoptera Collection, H-1088 \\ Budapest, Baross u. 13, Hungary.E-mail:vas.zoltan@nhmus.hu
}

\begin{abstract}
In this paper two new species of Campoletis Förster, 1869 (Ichneumonidae: Campopleginae) are described from Kenya: Campoletis clepsydra sp. n. and Campoletis kangalogba sp. n. Additionally, Campoletis cinctula (Holmgren, 1868), a species known only from South Africa so far, is first reported from Ethiopia, and further Ethiopian and South African records of Campoletis pedunculata (Enderlein, 1914) are given. With four figures.
\end{abstract}

Key words - distribution, new record, species description, taxonomy

This paper is dedicated to the memory of Dr. Ottó Merkl, honouring his long-lasting and remarkable collecting activity, which enriched the Hymenoptera Collection with thousands of specimens - including the type specimens of the newly described species in this paper.

\section{INTRODUCTION}

Campoletis Förster, 1869 is a species-rich genus of family Ichneumonidae, subfamily Campopleginae. Presently more than 110 valid species are known, most of them occurring in the Palaearctic and Nearctic regions (see e.g. RIEDEL (2017), VAs (2019a, b) and WEI et al. (2020) for most recent taxonomic works on the genus). However, Campoletis species of the Afrotropical region are rather poorly known; there are only three valid species in the region: Campoletis cinctula (Holmgren, 1868) and Campoletis sordicincta (Morley, 1916) known from South Africa, and Campoletis pedunculata (Enderlein, 1914) known from Namibia, Ethiopia, Kenya and South Africa (Townes \& Townes 1973, Yu et al. 2012). In this paper two new Campoletis species are described from Kenya, namely Campoletis clepsydra sp. n. and Campoletis kangalogba sp. n., the occurrence of Campoletis cinctula (Holmgren, 1868) is reported from Ethiopia, and further 
Ethiopian and South African records of Campoletis pedunculata (Enderlein, 1914) are given.

The examined Afrotropical Campopleginae material belongs to the Hungarian Natural History Museum (HNHM, Budapest, Hungary) and to the Biological Museum of Lund University (MZLU, Lund, Sweden); the former material is mainly resulted from the Elgon Expedition of HNHM in 1992, with Ottó Merkl's zoological leadership on the field (MER KL 1993).

Ichneumonidae taxonomy and nomenclature follow YU \& HorSTMANN (1997) and YU et al. (2012); complete nomenclatural history and list of synonym taxa are not repeated here, since they were given in detail in these references. Morphological terminology follows GAULD (1991) and GAULD et al. (1997); however, in the cases of wing veins the corresponding terminology of TOWNES (1969) is also indicated. Identifications were based on Holmgren (1868), Cameron (1905), Enderlein (1914), Morley (1916), Wilkinson (1927), SEYRIg (1935), Townes \& TownEs (1973), van NoorT (2021). Type materials of all Afrotropical Campoletis species (both valid and synonym ones) were examined at least by photos, except that of Zachresta pedunculata Enderlein, 1914 which was destroyed in Hamburg during the World War II (Townes \& Townes 1973). The photos were taken with a 14 MP MicroQ-U3L digital camera. Postimage work was done with ToupTek ToupView v4.7 and Photoshop CS6.

\section{RESULTS}

Subfamily: Campopleginae Förster, 1869

Genus: Campoletis Förster, 1869

Type species: Mesoleptus tibiator Cresson, 1864, included by Houghton (1907)

\section{Campoletis cinctula (Holmgren, 1868)}

Material - One female, Ethiopia, Akaki river, Addis Ababa, 6.X.1980, A. Demeter leg., swept, No. 120; one female, Ethiopia, Menagesha forest, Mount Muchacha, 3.XII.1980, A. Demeter leg., swept, No. 553; two males, RSA [= Republic of South Africa], Cape Province, De Hoop Nature Reserve, 34⒉ $20^{\circ} 25^{\prime} \mathrm{E}, 0-200 \mathrm{~m}, 10-13 . \mathrm{X} .1994$, R. Danielsson leg., loc. 12; one male, RSA [= Republic of South Africa], Cape Province, Wilderness N. Park, 17 km SE George, $33^{\circ} 59^{\prime}$ S, 22 $39^{\circ} \mathrm{E}$, 14.X.1994, R. Danielsson leg., loc. 18. The Ethiopian specimens and one South African male (from loc. 12) are deposited in HNHM, the remaining South African specimens are deposited in MZLU.

Remarks - First records from Ethiopia. This species was known only from South Africa (Townes \& Townes 1973, Yu et al. 2012). 


\section{Campoletis clepsydra sp. $\mathbf{n}$.}

(Figs 1-2)

Type material - Holotype: female, Kenya, Mt. Elgon Nat. P. [= National Park], bamboo (Arundinaria alpina) thicket, 2740m, 22.I.1992, O. Merkl \& G. Várkonyi leg., swept, No. 496, specimen card-mounted, Id. No. HNHM-HYM 155588. - Paratypes: female, Kenya, Mt. Elgon Nat. P. [= National Park], E slope of Chemwote, subalpine Ericaceae bush, 3300m, 21.I.1992, O. Merkl leg., swept, No. 493, specimen card-mounted, Id. No. HNHM-HYM 155589; two males, Kenya, Mt. Elgon Nat. P. [= National Park], near Chepnyalil Cave, dry evergreen montane forest, 2500m, 28.I.1992, A. Lobmayer, O. Merkl \& G. Várkonyi leg., swept, No. 507, specimens card-mounted, Id. No. HNHM-HYM 155590-155591. The holotype and the paratypes are deposited in HNHM.

Diagnosis - The new species can be reliably identified by the following character states in combination: apical margin of clypeus with a distinct, pointed median tooth; gena in dorsal view $0.7-0.8 \times$ as long as eye width, weakly narrowed behind eyes; malar space as long as basal width of mandible; propodeal carinae obsolete, except the anterior sections of lateromedian longitudinal carinae bordering the triangular area basalis and the reversed V-shaped anterior part of area superomedia; nervulus strongly postfurcal; lower external angle of second discal cell acute; ovipositor sheath $1.0-1.1 \times$ as long as hind tibia; scapus and pedicellus black; tegula yellow; metasoma dark, lateral parts of middle and apical tergites rusty reddish; fore and middle legs predominantly orange; hind coxa black, trochanter predominantly blackish, trochantellus yellow, femur reddish orange, basally and apically weakly darkened, tibia subbasally, internally and apically brown, basally and externo-medially pale yellowish to ivory.

Description - Female (Figs 1-2). Body length ca. 6.5-7 mm, fore wing length ca. $5.5 \mathrm{~mm}$.

Head: Antenna with 33 flagellomeres; first flagellomere $3.1-3.3 \times$ as long as its apical width; preapical flagellomeres longer than wide. Head transverse, matt, granulate; hairs short, greyish, on lower face and clypeus somewhat longer. Ocelli small, ocular-ocellar distance $1.3-1.4 \times$ as long as ocellus diameter, distance between lateral ocelli $1.4-1.5 \times$ as long as ocellus diameter. Inner eye orbits slightly indented, about parallel. Gena long, in dorsal view $0.7-0.8 \times$ as long as eye width, weakly narrowed behind eyes. Occipital carina complete, ventrally somewhat weakened, reaching hypostomal carina little before base of mandible; hypostomal carina elevated. Frons flat, impressed above toruli, median longitudinal carina indistinct. Face and clypeus almost flat in profile. Clypeus very weakly separated from face, its apical margin subtruncate with a relatively small but distinct, triangular, pointed median tooth. Malar space as long as basal width of mandible. Mandible strong, lower margin with moderately wide flange from base towards teeth, flange gradually narrowed before teeth; mandibular teeth of equal length. 
Mesosoma: Mesosoma matt, granulate without distinct punctures, and with short, dense, greyish hairs. Pronotum with weak, transverse and diagonal wrinkles on ventral half, epomia indistinct. Mesoscutum slightly longer than wide, moderately convex in profile; notaulus not developed. Scuto-scutellar groove wide and moderately deep. Scutellum convex in profile, lateral carinae not developed. Speculum very finely granulate to finely coriaceous, matt. Epicnemial carina relatively weak, pleural part bent to anterior margin of mesopleuron reaching it below its middle height, transversal part (i.e., the part at the level of sternaulus running through the epicnemium to the ventral edge of pronotum) not developed, ventral part (behind fore coxae) not elevated. Sternaulus indistinct. Posterior transverse carina of mesosternum complete. Metanotum 0.4-0.5 $\times$ as long as scutellum. Metapleuron without juxtacoxal carina; submetapleural carina complete, elevated. Pleural carina of propodeum relatively weak; propodeal spiracle small, circular, separated from pleural carina by about its length, connected to pleural carina by a distinct ridge. Propodeum granulate with weak, mostly transverse rugosity on posterior half, convex in profile. Propodeal carinae obsolete, except the anterior sections of lateromedian longitudinal carinae bordering area basalis and the anterior part of area superomedia; costulae obsolescent. Area basalis triangular, little longer than its basal width. Area superomedia rather elongate and narrow, pentagonal, anteriorly reversed $\mathrm{V}$-shaped, posteriorly opened, its lateral carinae posterior to costulae missing. Area petiolaris confluent with area superomedia, wide. Fore wing with petiolate, rectangular areolet, $3 \mathrm{rs}-\mathrm{m}$ present, second recurrent vein $(2 m-c u)$ little proximal to middle of areolet; distal abscissa of $R s$ about straight; nervulus (cu-a) postfurcal by about $0.2-0.3 \times$ its length, moderately inclivous; postnervulus (abscissa of $C u 1$ between $1 m-c u$ and $C u 1 a+C u 1 b$ ) intercepted slightly below its middle by $C u 1 a$; lower external angle of second discal cell acute. Hind wing with nervellus ( $c u-a+$ abscissa of $C u 1$ between $M$ and $c u-a$ ) about vertical, broken, intercepted by discoidella $(C u 1)$ at about its posterior third; discoidella spectral, proximally connected to nervellus. Coxae granulate. Hind femur ca. $5 \times$ as long as high. Inner spur of hind tibia ca. $0.5 \times$ as long as first tarsomere of hind tarsus. Tarsal claws small, as long as or little longer than arolium, basally weakly pectinate.

Metasoma: Metasoma moderately compressed, finely granulate to shagreened, and with dense, short hairs. First tergite relatively short and stout, ca. $2.5 \times$ as long as width of its apical margin; glymma strong; dorsomedian carinae of first tergite distinct. Second tergite stout, $1.1 \times$ as long as its apical width; thyridium oval, its distance from basal margin of tergite ca. $1.5 \times$ as long as its length. Posterior margins of apical tergites not excised. Ovipositor sheath relatively long, $2.1 \times$ as long as first tergite, $1.0-1.1 \times$ as long as hind tibia; ovipositor compressed, rather strong, upcurved, dorsal preapical notch deep.

Colour: Flagellum black to dark brown, scapus and pedicellus black. Head black, except palpi and mandible yellow, mandibular teeth dark. Mesosoma black, except tegula yellow. Metasoma black to dark brown, lateral parts of middle and 
apical tergites rusty reddish. Wings hyaline, wing veins and pterostigma brown. Fore and middle legs predominantly orange, coxae basally slightly darkened, trochanters, trochantelli and tibiae externally yellowish, apical tarsomeres darkened. Hind leg: coxa black; trochanter blackish, apically very narrowly yellowish; trochantellus yellow; femur reddish orange, basally and apically weakly darkened; tibia subbasally, internally and apically brown, basally and externomedially pale yellowish to ivory; tarsus brown, first tarsomere at extreme base narrowly yellowish.

Male: Similar to female in all characters described above, except: body length ca. $6 \mathrm{~mm}$, fore wing length ca. $4.5 \mathrm{~mm}$; ocular-ocellar distance 1.1-1.2x as long as ocellus diameter; mesoscutum dorsally more flattened than in female; second tergite $1.3 \times$ as long as its apical width; basal and apical dark patches of hind femur slightly more extensive and dark parts of hind tibia slightly darker than in female.

Distribution - Kenya.

Etymology - The specific epithet is derived from the Latinized noun clepsydra, meaning water clock, referring to the hourglass-shaped propodeal carinae bordering area basalis and the anterior part of area superomedia; noun in apposition, ending not to be changed.

Remarks on identification - Among the Afrotropical Campoletis species the new species is most similar to Campoletis pedunculata (Enderlein, 1914) due to the colouration pattern of hind tibia; however, the new species could be easily distinguished from that species by its distinct, pointed clypeal tooth and mostly obsolete propodeal carinae.

\section{Campoletis kangalogba sp. $\mathbf{n}$.}

(Figs 3-4)

Type material - Holotype: female, Kenya, Mt. Elgon Nat. P. [= National Park], SW ridge of Koroborte, subalpine Ericaceae bush, 3300m, 16.I.1992, O. Merkl leg., swept, No. 472, specimen card-mounted, Id. No. HNHM-HYM 155592. - Paratypes: one female and two males, same collecting data, specimens card-mounted, Id. No. HNHM-HYM 155593-155595, respectively. The holotype and the paratypes are deposited in HNHM.

Diagnosis - The new species can be reliably identified by the following character states in combination: apical margin of clypeus without a distinct, pointed median tooth; gena in dorsal view $0.6 \times$ as long as eye width, roundly narrowed behind eyes; malar space 1.1-1.2 $\times$ as long as basal width of mandible; propodeal carinae strong, except costulae obsolescent and median sections of lateromedian longitudinal carinae weak; area superomedia ca. $2 \times$ as long as wide, posteriorly closed; nervulus strongly postfurcal; lower external angle of second discal cell acute; ovipositor sheath $0.4 \times$ as long as hind tibia; scapus and pedicellus 
black; tegula yellow; metasoma black, posterior margins of tergites suffused with very dark brown; fore and middle legs predominantly orange; hind coxa black, trochanter predominantly dark brownish, trochantellus orange, femur orange, tibia orange-brown, subbasally and apically indistinctly darkened.

Description - Female (Figs 3-4). Body length ca. $5 \mathrm{~mm}$, fore wing length ca. $3.5 \mathrm{~mm}$.

Head: Antenna with 28 flagellomeres; first flagellomere ca. $3.5 \times$ as long as its apical width; preapical flagellomeres longer than wide. Head transverse, matt, granulate; hairs moderately short, greyish, on lower face and clypeus little longer. Ocelli small, ocular-ocellar distance $1.4-1.5 \times$ as long as ocellus diameter, distance between lateral ocelli $1.4-1.5 \times$ as long as ocellus diameter. Inner eye orbits slightly indented, about parallel. Gena moderately long, in dorsal view $0.6 \times$ as long as eye width, roundly narrowed behind eyes. Occipital carina complete, ventrally slightly weakened, reaching hypostomal carina little before base of mandible; hypostomal carina slightly elevated. Frons flat, impressed above toruli, median longitudinal carina indistinct. Face and clypeus weakly convex in profile. Clypeus very weakly separated from face, its apical margin convex, medially slightly produced but not forming a distinct, pointed median tooth. Malar space long, 1.1-1.2x as long as basal width of mandible. Mandible relatively short, lower margin with moderately wide flange from base towards teeth, flange gradually narrowed before teeth; mandibular teeth of equal length.

Mesosoma: Mesosoma matt, granulate without distinct punctures, and with short, dense, greyish hairs. Pronotum with weak, transverse and diagonal wrinkles on ventral half, epomia distinct. Mesoscutum about as long as wide, convex in profile; notaulus not developed. Scuto-scutellar groove wide and deep. Scutellum convex in profile, lateral carinae not developed. Speculum very finely granulate to almost smooth. Epicnemial carina strong, pleural part bent to anterior margin of mesopleuron reaching it below its middle height, transversal part (i.e., the part at the level of sternaulus running through the epicnemium to the ventral edge of pronotum) not developed, ventral part (behind fore coxae) slightly elevated. Sternaulus indistinct. Posterior transverse carina of mesosternum complete. Metanotum $0.4-0.5 \times$ as long as scutellum. Metapleuron without juxtacoxal carina; submetapleural carina complete, elevated. Pleural carina of propodeum strong; propodeal spiracle small, circular, separated from pleural carina by about its length, connected to pleural carina by a distinct ridge. Propodeum granulate with weak, mostly transverse rugosity on posterior half, convex in profile. Propodeal carinae strong, except costulae obsolescent and lateromedian longitudinal carinae weak between costulae and posterior transverse carina. Area basalis as long as or little longer than its basal width, either triangular or posteriorly strongly narrowed trapezoidal. Area superomedia rather elongate and narrow, ca. $2 \times$ as long as wide, posteriorly closed. Area petiolaris wide. Fore wing with petiolate, rectangular areolet, $3 r s-m$ present, second recurrent vein $(2 m-c u)$ little proximal to middle of areolet; distal abscissa of $R s$ almost straight to slightly 
curved towards wing margin; nervulus $(c u-a)$ postfurcal by about $0.2-0.3 \times$ its length, inclivous; postnervulus (abscissa of $C u 1$ between $1 m-c u$ and $C u 1 \mathrm{a}+\mathrm{Cu1b}$ ) intercepted distinctly below its middle by $C u 1 a$; lower external angle of second discal cell acute. Hind wing with nervellus $(c u-a+$ abscissa of $C u 1$ between $M$ and $c u-a)$ weakly reclivous, broken, intercepted by discoidella ( $C u 1)$ at about its posterior third; discoidella spectral, proximally connected to nervellus. Coxae granulate. Hind femur slender, 5.5-6.1 $\times$ as long as high. Inner spur of hind tibia ca. $0.5 \times$ as long as first tarsomere of hind tarsus. Tarsal claws small, as long as arolium, basally weakly, indistinctly pectinate.

Metasoma: Metasoma moderately compressed, finely granulate to shagreened, and with dense, short hairs. First tergite relatively short and stout, ca. $2.5 \times$ as long as width of its apical margin; glymma strong; dorsomedian carinae of first tergite distinct. Second tergite moderately elongate, $1.4-1.5 \times$ as long as its apical width; thyridium oval, its distance from basal margin of tergite ca. $1.5 \times$ as long as its length. Posterior margins of apical tergites not excised. Ovipositor sheath short, $0.7 \times$ as long as first tergite, $0.4 \times$ as long as hind tibia; ovipositor compressed, straight.

Colour: Flagellum black to very dark brown, scapus and pedicellus black. Head black, except palpi light orange and mandible faint yellow, mandibular teeth dark. Mesosoma black, except tegula yellow. Metasoma black, posterior margins of tergites suffused with very dark brown. Wings hyaline, wing veins and pterostigma brown. Fore and middle legs predominantly orange, coxae basally more or less darkened and tarsi apically brownish. Hind leg: coxa black; trochanter dark brownish, apically narrowly yellowish brown; trochantellus orange; femur entirely orange; tibia orange-brown, subbasally and apically indistinctly darkened; tarsus brownish.

Male: Similar to female in all characters described above, except: first flagellomere ca. $3 \times$ as long as its apical width; mandible brighter yellow than in female; fore and middle coxae more extensively darkened than in female; hind trochantellus partly light brownish; hind femur brownish orange.

Distribution - Kenya.

Etymology - The new species is named after Kangalogba, a female primordial spirit and mother of the creator god Tororut in the Kenyan and Ugandan Pokot and Suk mythology, usually personified as a dragonfly or a woman with insect wings; proper noun in apposition, ending not to be changed.

Remarks on identification - Among the Afrotropical Campoletis species Campoletis kangalogba sp. $\mathrm{n}$. is not quite similar to any known species of the genus; it can be readily identified by its propodeal carination, short ovipositor, dark metasoma, and colouration of hind legs. 


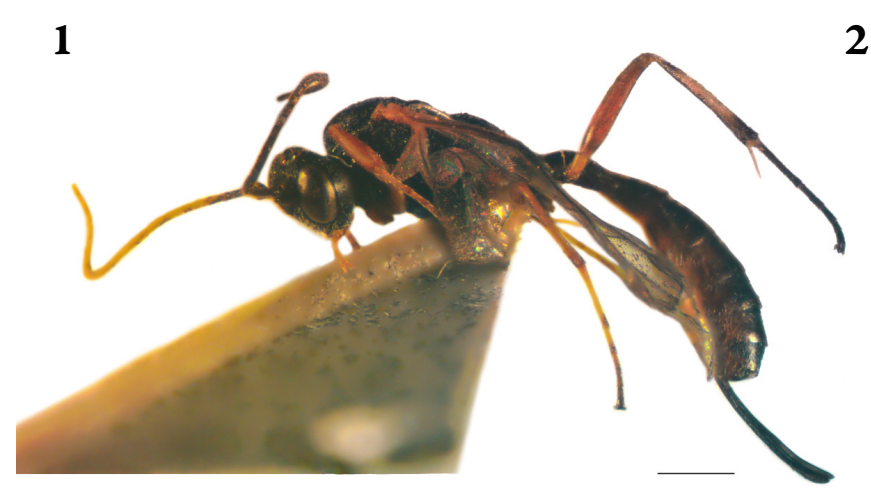

2
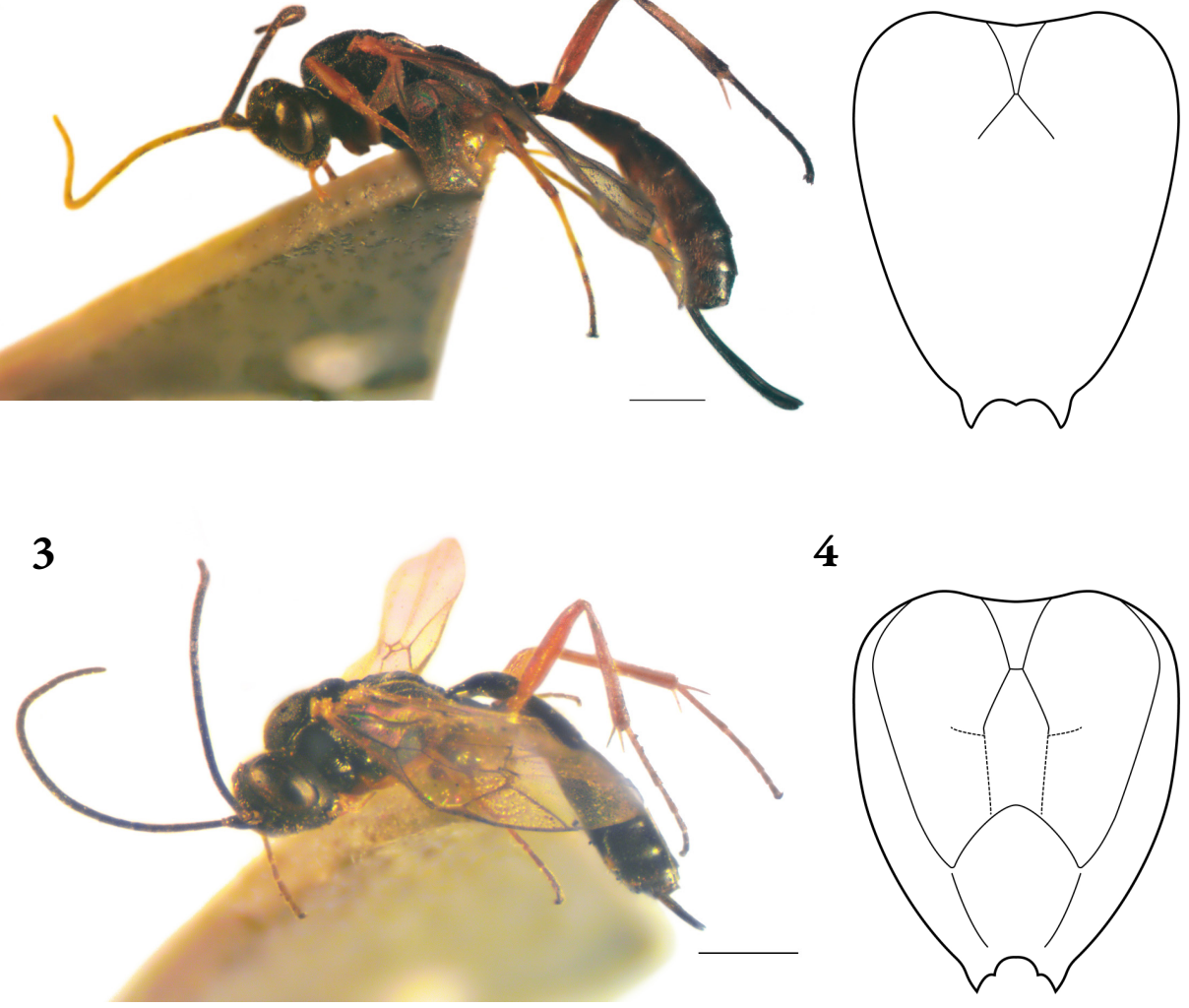

4

Figures 1-4. New Campoletis species: $1=$ Campoletis clepsydra sp. n., holotype; $2=$ Campoletis clepsydra sp. n., propodeum; 3 = Campoletis kangalogba sp. n., holotype; 4 = Campoletis kangalogba sp.n., propodeum

\section{Campoletis pedunculata (Enderlein, 1914)}

Material - Two males, Abyssinia [= Ethiopia], Maraquo [= Mareqo], XI.1912, Ö. Kovács leg.; two females, Ethiopia, Akaki river, Addis Ababa, 30.IX.1980, A. Demeter leg., swept, No. 93; one female and one male, Ethiopia, Ambo, 23.XI.1980, A. Demeter leg., swept, No. 513; one female, Ethiopia, Menagesha forest, Mount Muchacha, 3.XII.1980, A. Demeter leg., swept, No. 553; two males, RSA [= Republic of South Africa], Cape Province, $2 \mathrm{~km} \mathrm{NW}$ Darling, $33^{\circ} 22^{\prime} \mathrm{S}, 18^{\circ} 22^{\prime} \mathrm{E}, 170 \mathrm{~m}, 4 . X .1994$, R. Danielsson leg., loc. 4; one female, RSA [= Republic of South Africa], Cape Province, Piekenierskloof, $15 \mathrm{~km} \mathrm{~S}$ Citrusdal, $32^{\circ} 38^{\prime} \mathrm{S}, 18^{\circ} 57^{\prime} \mathrm{E}, 370 \mathrm{~m}, 5 . X .1994$, R. Danielsson leg., loc. 4; 9 females and one 
male, RSA [ = Republic of South Africa], Cape Province, Koomplans-kloof, $10 \mathrm{~km}$ S Citrusdal, $32^{\circ} 40^{\prime} \mathrm{S}, 1^{\circ} 01^{\prime} \mathrm{E}, 200-270 \mathrm{~m}, 4-8 . X .1994$, R. Danielsson leg., Malaise trap, loc. 6; one female, RSA [= Republic of South Africa], Cape Province, Hexrivier, N of Citrusdal, 32 $26^{\prime}$ S, $18^{\circ} 58^{\prime} \mathrm{E}, 6 . \mathrm{X} .1994$, R. Danielsson leg., loc. 8; one female, RSA [= Republic of South Africa], Cape Province, Cedarberg, $3 \mathrm{~km}$ ESE Kriedowkrans, $32^{\circ} 22^{\prime}$ S, $1^{\circ} 59^{\prime} \mathrm{E}, 350 \mathrm{~m}, 6 . X .1994$, R. Danielsson leg., loc. 10; one male, RSA [= Republic of South Africa], Natal, $17 \mathrm{~km}$ NE Empangeni, Nseleni River, 2842’S, 3201'E, 24.X.1994, R. Danielsson leg., loc. 32. The Ethiopian specimens are deposited in HNHM, the South African specimens are deposited in MZLU.

Remarks - This species is already known from Ethiopia and South Africa (and also from Namibia and Kenya); however, as its distributional records in literature are scarce and were published several decades ago (Townes \& TownES (1973) is the latest), it may be worthwhile to report these more recent records.

Acknowledgements - Thanks are due to Rune Bygebjerg (MZLU) for providing some of the examined South African material, and to Viktória Szőke (HNHM) for drawing and post-image works. This paper was supported by the János Bolyai Research Scholarship of the Hungarian Academy of Sciences.

\section{REFERENCES}

Cameron P. 1905: On the Hymenoptera of the Albany Museum, Grahamstown, South Africa. Record of the Albany Museum 1: 161-176.

Enderlein G. 1914: Hymenoptera IV: Ichneumonidae. - In: Michaelsen W. (ed.): Beiträge zur Kenntnis der Land-und Süsswasserfauna Deutsch-Südwestafrikas. Band 1. Hamburg, pp. 1-452.

GAULD I. D. 1991: The Ichneumonidae of Costa Rica, 1. Introduction, keys to subfamilies, and keys to the species of the lower Pimpliform subfamilies Rhyssinae, Poemeniinae, Acaenitinae and Cylloceriinae. - Memoirs of the American Entomological Institute 47: 1-589.

Gauld I. D., Wahl D., Bradshaw K. Hanson P. \& Ward S. 1997: The Ichneumonidae of Costa Rica, 2. Introduction and keys to species of the smaller subfamilies, Anomaloninae, Ctenopelmatinae, Diplazontinae, Lycorininae, Phrudinae, Tryphoninae (excluding Netelia) and Xoridinae, with an appendix on the Rhyssinae. - Memoirs of the American Entomological Institute 57: 1-485.

Holmgren A. E. 1868: Hymenoptera. Species novas descripsit. - Kongliga Svenska Fregatten Eugenies Resa omkring Jorden, Zoologi 6: 391-442.

Houghton C. O. 1907: Reports of the Delaware College Agricultural Experimental Station. Reports 16-18: 89 . 
Mer KL O. 1993: Zoological collectings by the Hungarian Natural History Museum in Africa: a report on the Elgon expedition, 1992. - Miscellanea Zoologica Hungarica 8: 51-64.

Morley C. 1916: On some South African Ichneumonidae in the collection of the South African Museum. - Annals of the South African Museum 15: 353-400. https://doi.org/10.5962/bhl.part.22198

Riedel M. 2017: The Western Palaearctic species of the genus Campoletis Förster (Hymenoptera, Ichneumonidae, Campopleginae). - Spixiana 40(1): 95-137.

SEYRIg A. 1935: Mission scientifique de l'Omo. Tome III. Fascicule 18. Hymenoptera, II. Ichneumonidae: Cryptinae, Pimplinae, Tryphoninae et Ophioninae. - Mémoires $d u$ Muséum National d'Histoire Naturelle, Paris 4: 1-100.

Townes H. 1969: The genera of Ichneumonidae. Part 1. - Memoirs of the American Entomological Institute 11: 1-300.

Townes H. \& Townes M. 1973: A catalogue and reclassification of the Ethiopian Ichneumonidae. - Memoirs of the American Entomological Institute 19: 1-416.

van Noort S. 2021: WaspWeb: Hymenoptera of the Afrotropical region. Available from: http://www.waspweb.org [Accessed 16 June 2021.]

VAS Z. 2019a: Contributions to the taxonomy, identification, and biogeography of the Western Palaearctic species of Campoletis Förster (Ichneumonidae: Campopleginae). - Zootaxa 4565(3): 373-382.

https://doi.org/10.11646/zootaxa.4565.3.4

VAS Z. 2019b: New species and new records of Campopleginae from the Palaearctic region (Hymenoptera: Ichneumonidae). - Folia entomologica hungarica 80: 247-271.

https://doi.org/10.17112/FoliaEntHung.2019.80.247

Wei Y.-W., Zhou Y.-B., Zou Q.-C. \& Sheng M.-L. 2020: A new species of Campoletis Förster (Hymenoptera, Ichneumonidae) with a key to species known from China, Japan and South Korea. - ZooKeys 1004: 99-108.

https://doi.org/10.3897/zookeys.1004.57913

WiLkinson D. S. 1927: On three new species of Ichneumonidae. - Bulletin of Entomological Research 17(4): 417-420. https://doi.org/10.1017/S0007485300019532

YU D. S. \& Horstmann K. 1997: A catalogue of world Ichneumonidae (Hymenoptera). - The American Entomological Institute, Gainesville, 1558 pp.

Yu D. S., van AChterberg C. \& Horstmann K. 2012: Taxapad 2012, Ichneumonoidea 2011. Database on flash-drive. www.taxapad.com, Ottawa, Ontario, Canada. 


\title{
Tudományra új afrotropikus Campoletis Förster, 1869 fürkészdarázsfajok és új előfordulási adatok (Hymenoptera: Ichneumonidae: Campopleginae)
}

\author{
VAs ZOLTÁN \\ Magyar Természettudományi Múzeum, Állattár, Hártyásszárnyúak gyüjteménye, \\ H-1088 Budapest, Baross u. 13, Magyarország. \\ E-mail:vas.zoltan@nhmus.hu
}

Összefoglalás - Jelen munkában a Campoletis Förster, 1869 nemzetség két tudományra új afrotropikus (kenyai) fajának - Campoletis clepsydra sp. n. és Campoletis kangalogba sp. n. leírását, a mostanáig csak Dél-Afrikából ismert Campoletis cinctula (Holmgren, 1868) első etiópiai előfordulási adatait és a Campoletis pedunculata (Enderlein, 1914) újabb etiópiai és délafrikai adatait közli a szerző. Négy ábrával.

Kulcsszavak - taxonómia, fajleírás, elterjedés, új előfordulási adat

\section{ÁBRAMAGYARÁZATOK}

1-4 ábra. Tudományra új Campoletis fajok: 1 = Campoletis clepsydra sp. n., holotípus;

2 = Campoletis clepsydra sp. n., áltorszelvény; 3 = Campoletis kangalogba sp. n., holotípus; 4 = Campoletis kangalogba sp. n., áltorszelvény 